\title{
The ROI of Diverting Water from Tibet to North China: A Feasibility Study
}

\author{
Dingfeng Zhao \\ Xiamen University Tan Kah Kee College, Xiamen, China

\section{从投入产出的角度分析藏水北调的可取性问题} \\ 赵定烽 \\ 厦门大学嘉庚学院, 厦门, 中国
}

\begin{abstract}
This research looks deeply into hotly discussed projects for diverting water from Tibet to North China in view of management, and then finds out that the ROI of any of these projects is not high enough. Since it is too resource-intensive to be effective and too time-consuming to be efficient, probably none of these projects is adaptable nor applicable.
\end{abstract}

Keywords-interbasin water diversion;diverting water from Tibet to North China; desertification control; agriculture \& animal husbandry \& forestry; Hongqi Canal

摘要一本文从管理学角度深入分析了热议中的多种藏水北调方 案, 认为各方案投入产出比不高。因成本投入大、效果差, 时间 投入长、效率低, 以上各方案都不足取。 河

关键词一跨流域调水; 藏水北调; 荒漠治理; 农牧林; 红旗

\section{I. 引言}

很多学者及追随者们都把中国水资源突破希望寄托于 藏水或西南水跨流域北调(包括雅鲁藏布江、怒江和澜沦江 等及其它少数次要出境河水之汇集跨流域远输)。这些主张 如 “大西线调水工程(耗资 2250 亿, 年引水量相当“四条黄 河”)、郭开等主张的朔天运河(调水 2000 亿吨/年)、王梦恕 院士主张的藏水入疆(调水 100 150 亿吨/年, 成本 1 万亿 元)、和最近热炒的以王浩院士为首的所谓“S4679”课题研究 组的红旗河计划(包括雅鲁藏布江、怒江、澜沦江、金沙江、 雅聋江等共计年调水 600 亿吨, 成本 4 万亿元)。特别是红 旗河工程, 因其热炒, 故略加细述: 据称该工程线路长 6188 千米相当于长江, 年输水仅 600 亿吨相当于黄河, 工程设 计自雅鲁藏布江大拐弯附近开始, 沿青藏高原边缘终抵新 疆喀什, 另有支渠红延河据说抵达延安、春风河抵达哈密、 漠北河东抵呼和浩特并最终拓展至京西地区云云。

其实无论年调水 2000 2250 亿吨、或 100 150 亿吨、或 600 亿吨都远非提倡者那样声称的可解决中国水短缺以达
到 “救中国”之目的。事实所有这些建议对于目的而言, 都只是 “杯水车薪” , 其结局只可能是就像已建成的东、 中线南水北调工程那样 “烂尾楼”。因为南水北调东线只 实现设计规划数的近 $6 \%$ 年调水量、中线则始终未达其半, 2018 年计划调水 58 亿吨, 仅为其首期设计能力的年调水 130 亿吨的 44.6\%, 且规划则中的受益省市的豫、冀、津、 京等 4 省市的余 3 省市因水定价高而放弃, 只剩主要受益 者河南省(因其水定价最低而才获利)。事实上, 任何欲解决 中国水短缺的方案, 如果未超过年调水 1 万亿吨的任何其 它方案, 均是烂尾楼。而提供年调水超万亿吨的方案唯有 立足于河口水的调水方案：东水西调(综合年调水方案达 13255 亿吨) ${ }^{\mathbf{I} 11}$, 否则便无任何替代水源, 除非源淡化海水。 但源淡化海水的输送成本远较输送河口水西调大! 因两者 间管道造价大致相当，但前较后者少几个成本大项：即淡 化工厂造价(主项)和运行管理折旧费(次项), 而主项成本便 数倍于管道造价。

本文就当前热炒的形形式式藏水北调论而言，作投入产 出的目的性分析, 其是否可取? 主要论点是下面 2 则: (1) 西藏水到底多余不？或西藏能否当地水消化？(2)当地水 消化与异地水消化那个有利? 请见下面分析。

\section{II. 西藏水多余不?}

众所周知, 西藏国土面积大, 达 120 多万千米 ${ }^{2}$, 在中 国的一级行政区仅次于新疆(面积 160 多万千米 ${ }^{2}$ ), 又据文 献 2 之前言部分讲，西藏大部分生境条件具有高寒性、干 旱性、多变性特点。西藏人口 277 万(2005 年), 目前仅有 500 万亩耕地, 草地面积 82.667 万千米 ${ }^{2}$, 占国土面积 $69.1 \%$ 。 西藏的荒漠化土地的年降水通常只有 100 毫米水平或略多, 比较巴丹吉林沙漠年降水为 300 400mm, 便可知西藏水到 底多余不多余? 
表 I 西藏可供发展农业的区划表列（作者据文献 2 得出）

\begin{tabular}{|c|c|c|c|}
\hline 序号 & 区划编号 & 功能区名称 & 面积 $\left(\mathrm{km}^{2}\right)$ \\
\hline 1 & $\mathrm{II}_{1-4}$ & 尼洋河中下游宽谷特色农林产业与生态旅游生态功能区 & 7292.38 \\
\hline 2 & $\mathrm{II}_{1-6}$ & 米林谷地农业与土壤保持生态旅游生态功能区 & 7592.58 \\
\hline 3 & $\mathrm{II}_{1-7}$ & 加查-朗县谷地农业与土壤保持生态功能区 & 10483.02 \\
\hline 4 & $\mathrm{II}_{2-1}$ & 边坝-洛隆怒江山原谷地农牧业与土壤保持生态功能区 & 10804.63 \\
\hline 5 & $\mathrm{II}_{2-2}$ & 丁青高原谷地牧农业与土壤保持生态功能区 & 6849.69 \\
\hline 6 & $\mathrm{II}_{2-5}$ & 八宿山原河谷牧农业与土壤保持生态功能区 & 14270.53 \\
\hline 7 & $\mathrm{II}_{2-6}$ & 察雅-贡觉河谷盆地农牧业开发与土壤保持生态功能区 & 15145.51 \\
\hline 8 & $\mathrm{II}_{3-6}$ & 左贡怒江河谷山地特色农林业与土壤保持和生物多样性保护生态功能区 & 15342.53 \\
\hline 9 & $\mathrm{II}_{3-2}$ & 茫康滇金丝猴生物多样性保护与特色农林产品和生态旅游生态功能区 & 13022.63 \\
\hline 10 & $\mathrm{III}_{1-1}$ & 比如-索县-巴青山原谷地牧农业与土壤保持和水源涵养生态功能区 & 21596.48 \\
\hline 11 & $\mathrm{IV}_{1-1}$ & 萨嘎-奔顶段河谷农业与土壤保持生态功能区 & 5077.99 \\
\hline 12 & $\mathrm{IV}_{1-4}$ & 多雄藏布和美曲藏布下游谷地牧农业与土壤保持(风蚀、水蚀)生态功能区 & 4286.98 \\
\hline 13 & $\mathrm{IV}_{1-5}$ & 吉曲-萨迦曲宽谷农业重点发展与土壤保持和荒漠化控制生态功能区 & 7892.78 \\
\hline 14 & $\mathrm{IV}_{1-6}$ & 夏布曲-年楚河中下游宽谷灌溉农业重点发展与土壤保持生态功能区 & 5365.62 \\
\hline 15 & $\mathrm{IV}_{1-8}$ & 大那浦曲-汀曲下游宽谷农业与土壤保持及荒漠化控制生态功能区 & 65.9434 \\
\hline 16 & $\mathrm{IV}_{1-10}$ & 尼木-曲水宽谷农业与小气候调节生态功能区 & 3673.84 \\
\hline 17 & $\mathrm{IV}_{1-11}$ & 拉萨-贡嘎=扎囊宽谷灌溉农业重点发展与防洪、防风固沙生态功能区 & 7498.63 \\
\hline 18 & $\mathrm{IV}_{1-12}$ & 泽当-曲松宽谷灌溉农业重点发展与防洪和小气候调节生态功能区 & 7717.22 \\
\hline 19 & $\mathrm{IV}_{1-14}$ & 德庆-古荣山原谷盆地农牧业与水源涵养和土壤保持生态功能区 & 7717.22 \\
\hline 20 & $I_{2-1-4}$ & 朋曲中上游宽谷牧农业适度发展与水源涵养生态功能区 & 9558,15 \\
\hline 21 & $\mathrm{IV}_{2-4}$ & 年楚河-夏布曲上游农牧业适度发展与水源涵养生态功能区 & 11.62 .83 \\
\hline 22 & $\mathrm{IV}_{2-6}$ & 洛扎雄曲上游谷地农牧业与生物多样性保护与水源涵养生态功能区 & 6297.03 \\
\hline 23 & $\mathrm{IV}_{2-6}$ & 娘姆江-达旺河上游谷地农牧业与水源涵养和生物多样性保护生态功能区 & 4905.13 \\
\hline 24 & $\mathrm{IV}_{2-8}$ & 西巴霞曲上游谷地农牧业与土壤保持生态功能区 & 8252.56 \\
\hline \multirow[t]{2}{*}{25} & $\mathrm{IV}_{2-8}$ & 普兰县农牧业适度发展与古生物遗迹保护生态功能区 & 3211.96 \\
\hline & & 总面积 & 220763.23 \\
\hline
\end{tabular}

又据表 1 可知、西藏可供适度农业开发的规划面积达 22 万多千米 ${ }^{2}$, 若按山东省的耕地开发强度计 (垦殖率 $48.3 \%$ ), 可得耕地 1.6 亿亩, 按每产 1 千克粮耗水 2 吨计, 假定西藏 青稞亩产 231 千克计(亩产低地 300 千克, 高地 200 千克, 平均 231 千克), 1.6 亿亩耕地种青稞则可产青稞 3700 万吨 (其中 1.55 亿亩是新增耕地), 年耗水 736 亿吨(其中 716.1 亿吨年耗水量是新增量)。又据王梦恕院士规划, 年调出水 100 150 亿吨, 相应总年调水 600 亿吨的红旗河计划是 1 条 多黄河水量, 内雅鲁藏布江年调水也只最多调 150 200 亿 吨水平, 如此消耗还剩多少水可供外调? 也许雅鲁藏布江 将滴水无存哩! 另外考虑西藏有荒漠化土地 43.35 万千米 ${ }^{2}$, 占国土面积 36.13\%, 占国土面积 14.93\%的石漠化土地姑且 可不管(18.22 万千米 $\left.{ }^{2}\right)$, 如灌溉牧草以 $150 \mathrm{~mm}$ 的年降水标 准, 需水 650 亿吨还多, 西藏将来还要开发林业、矿业、 旅游业等, 人口也必然会增加, 相应生活用水也将增加, 城市耗水也相应要增加。可见不远的将来, 藏水其实本地 消化也尚且不够而得行施节水。西藏其实根本无水可调！

既然无水可调, 那为何建外调水工程呢? 建这些工程只 图个 GDP 增长数还是个其它目的啥?

\section{III. 当地消化与异地消化那个有利?}

显然据前面所言, 如西藏不搞沙漠治理、矿产开发、旅 游发展和城市建设的话, 也许有能力从雅鲁藏布江、怒江、 澜沦江、金沙江、雅聋江、大渡河等 6 河及其它较小的出 境河中总年调水 600 亿, 其中譬如雅鲁藏布江年 150 亿吨 左右、怒江年 95 亿吨左右、澜沦江年 105 亿吨左右、金沙 江 140 亿吨左右、雅聋江 50 亿吨左右、大渡河 60 亿吨左 右, 其它出境河 20 亿吨左右。当然忽略或考虑了出境河下 游的境外地区的各方面影响(通常是负面的, 请比较南水北 调中东仅规划年调水 278 亿吨, 而长江总水量是年产水量 高达 9802 亿吨, 上述 278 亿吨只占总产水量的 $2.84 \%$, 就 已经对长江中下游的汉水、鄱阳湖及上海长江口产生严重 负面影响。一些更有见识的主张少是不调长江上游金沙江 及支流雅䶭江、大流河水, 主调河口水更有助于生态平衡(见 文献 1)。

如果调雅鲁藏布江水, 印度和孟加拉国肯定有意见、调 怒江会影响到缅甸、调澜沦江则会影响缅甸、老挝、柬埔 寨及越南, 外交会很麻烦, 但就地消化则下游国家很难指 责, 若外调水则会强烈指责的。前面已经讲到, 西藏其实 无水可调。 
以王梦恕院士案年调水 100 150 亿吨的造价 1 万亿，按 红旗河调水案, 年调水 600 亿吨造价 4 万亿, 两者造吨造 价大致一致。问题是, 花如此大代价投入以调水, 其目的 何在? 除了搞航运或旅游外便毫无意义。如引水并让其在 途中蒸发一部分、污染一部分、渗透一部分, 然后在甘肃 河西走廊以后的约 4200 千米段两边宽 20 千米左右建造绿 洲、开始种地或灌溉牧场和林地, 然后移民。问题是高海 拔的西藏同样可移民！玻利维亚行政首都拉巴斯平均海拔 3600 米, 比拉萨还高, 而西藏林芝等地则比拉萨海拔还低。 新疆土地引水后当然可以开垦 2 亿亩(按红旗河规划算)、但 同样西藏也适合塘近 1.6 亿亩(见前面文), 这只比红旗河计 划少了 4 千万亩, 为这区区四千万亩耕地多花 4 万亿造价 合算否? 显然不合算。

况且不应计算表面上的耕地数, 而更应该计算实际产粮 数。产出多少吨粮需多少吨水是比例的。600 亿吨水全部种 粮也只产 0.3 亿吨粮, 无论 2 亿亩或 1.6 亿亩或 0.6 亿亩(一 年两熟加高产)都无关紧要。

因此, 为什么还要将水千辛万苦地调新疆再垦荒再将粮 调至东南, 好像流动能产生利润似的。但水的这样流动不 但不产生效益反而产生各种灾害（那些因调水必然产生的 地震、洪水、凌汗、塌方、水污染、水蒸发、水渗漏、盐 碱化及其它生态灾难），那又何必呢？

因为西藏当地也可种粮林和牧草，农林牧总是需要的。 西藏的粮食作物的冬春小麦、鸡爪谷、青稞和土豆、油菜 和踠豆、甚至虫桑, 产自新疆或产自西藏会有多少区别的? 也许西藏更好些, 因为其高原, 昼夜温差大、有利养分积 累, 因而品质更好些。虽然西藏可能路差些, 运费会高, 但路程短许多, 西藏调粮是东调, 新疆调粮则南调, 总起 来两者差不多, 只要出藏后, 路途将转好, 而且将来西藏 的路也会变好的。既然那么大代价的渠都要修, 其百分之 一的代价改造出藏的路也就好得不行, 那为何要将水那么 复杂的倒来倒去的?

最后还要问, 将荒漠留在西藏或留在新疆会有多大区别 的? 显然留新疆好! 因为新疆是孤立的, 相反西藏少了荒 漠, 会对长江、黄河及西南均有好处, 相反西藏荒漠增大, 则损害的也是长江、黄河及西南地区。所以西藏水本地消 化事实优于外调。其次西藏粮肉外调至中国的东南与新疆 粮外调的区别是新疆的路好, 但西藏外调的路途近得多, 约只有新疆路途的一半甚至还少, 两者相比仍然外调西藏 粮肉比较合算。

\section{IV. 结束语}

最后, 我们从上面的投入产出角度分析, 可以得出如下 的结论是：藏水北调不可取, 更可取的做法是尽量当地消 化。在西藏的范围内种粮、种植牧草、开发城市和旅游、 采矿业等着手对西藏水消化(而且得节约用水), 才能收获更 大的效益。这个效益远大于通常想像的, 将藏水调疆, 然 后再建造绿洲, 向绿洲移民、垦荒种粮, 再调粮到东南, 远不如直接向西藏移民、在当地多种经营有消耗其多余的 藏水(如果有的话)、就地消化藏水, 调粮向东, 更有利, 更 少外交纠纷、更利于生态、更减少运输里程、同时省 4 万 亿公积投资(譬如红旗河工程)。

\section{REFERENCES}

[1] Dingfeng Zhao, Batter Diverting Water from East China to North China via Channels or Tunnels than Diverting water from South China to the North, China New Telecommunication,No.17,V0l.20,2018,9,P.237-239

[2] TAR Environment Protection Bureau, National Western Development Strategy Office of TRA, The Ecological Function Zoning of Tibet Autonomous Region (Abridged Edition), 2006-06 